\title{
ORIGINAL
}

\section{Starch digestion by parotid amylase in the gastrointestinal tract of exocrine pancreatic insufficient rats}

\author{
Masashi Kurahashi and Koshiro Inomata* \\ Department of Medical Sciences, School of Nursing and Social Services, Health Sciences University of Hokkaido \\ (Chief : Prof. Masashi Kurahashi) \\ *Department of Oral Physiology, School of Dentistry, Health Sciences University of Hokkaido \\ (Chief : Prof. Koshiro Inomata) \\ 1757 Kanazawa, Ishikari-Tobetsu, Hokkaido 061-02, Japan \\ 〔Received on February 5, 1996 ; Accepted on June 4, 1996〕
}

Key words : parotid amylase/starch digestion/exocrine pancreatic insufficiency

\begin{abstract}
Amylase secretion from parotid glands and the pancreas into the gastrointestinal tract and starch digestion by amylase in the gastrointestinal tract during feeding were investigated in exocrine pancreatic insufficient rats which were free from cholestasis. The parotid amylase activity in the fasting state and amylase activity in the gastric content after feeding were similar for both the exocrine pancreatic insufficient rats and the control rats. In the exocrine pancreatic insufficient rats, amylase secretion from the pancreas decreased markedly, and a large part of the amylase activity in the small intestine and in the intestinal content after feeding was of the parotid type. However, the percentage of residual starch decreased from 86.8 in the pellet diet to 12.0 in the intestinal contents. These results suggest that the increased amylase activity in parotid glands is not necessary for the physiological role of parotid amylase in the gastrointestinal tract of rats with reduced secretion of pancreatic amylase, and that parotid amylase is the main starch digestive enzyme in the gastrointestinal tract of exocrine pancreatic insufficient rats as well as in rats with pancreatitis during feeding.
\end{abstract}

抄録：胆汁分泌不全を伴わない膵外分泌不全ラットを用い，摂食時の耳下腺および膵から胃腸管内へのアミ ラーゼ分泌およびこれらのアミラーゼによるデンプン消化について検討した。絶食時の耳下腺アミラーゼ活性お よび摄食後の胃内容中アミラーゼ活性は膵外分泌不全群と対照群との間に差はなかった。脺外分泌不全ラットで は脺からのアミラーゼ分泌は著明に減少しており，摂食後の膵外分泌不全群の小腸および腸内容アミラーゼ活性 の大部分は耳下腺型であった。しかしながら，残存するデンプンの割合は固形飼料中の $86.8 \%$ から，小腸内では $12.0 \%$ に減少していた。これらの結果から, 膵アミラーゼ分泌の減少したラットの胃腸管内における耳下腺アミ ラーゼの生理作用発現の条件として, 耳下腺アミラーゼ活性の増加は必須ではなく, 膵炎ラット同様に膵外分泌 不全ラットにおいても, 耳下腺アミラーゼが摂食中の胃腸管における主要なデンプン消化醭素であることが示唆 された。

\section{Introduction}

In our previous study ${ }^{1)}$, we induced pancreatitis in rats by ligation of the common bile duct close to the orifice into the duodenum, and clarified that amylase secreted from the parotid glands and moved from the stomach to the small intestine during feeding plays a physiological role in starch digestion in the gastrointestinal tract of rats with reduced secretion of pancreatic amylase. In these model rats, however, chronic cholestasis is accompanied with exocrine 
pancreatic insufficiency. Chronic absence of bile in the intestinal tract may affect both parotid-type amylase activity and starch digestion in the intestinal tract during feeding. Moreover, the parotid amylase activity in the rats with pancreatitis was higher than in the sham-operated control rats in the fasting state.

In order to clarify the physiological role of parotidtype amylase in starch digestion in the gastrointestinal tract of exocrine pancreatic insufficient rats which were free from cholestasis, this study investigated the effect of exocrine pancreatic insufficiency alone on both the amylase secretion from the parotid glands and the pancreas into the gastrointestinal tract and starch digestion by amylase in the gastrointestinal tract during feeding.

\section{Materials and Methods}

All animal protocols followed the Guiding Principles for the Care and Use of Animals approved by the Council of the Physiological Society of Japan.

\section{Animals}

Forty-nine male Wistar rats, 7 weeks old and weighing from 190 to $220 \mathrm{~g}$ (Shizuoka Laboratory Animal Center), were housed individually in an airconditioned room $\left(23 \pm 2^{\circ} \mathrm{C}\right.$, lights on from 8 a. m. to 8 p. m.) and fed a commercial pellet diet (Oriental Yeast) and water ad libitum for 2 weeks prior to use.

\section{Experimental procedure}

In the first experiment, the effects of exocrine pancreatic insufficiency were examined in the fasting state. At 9 weeks of age, exocrine pancreatic insufficiency in rats was induced by a single injection of 50 $\mu l$ of oleic acid (Sigma) into the pancreatic duct under sodium pentobarbital anesthesia $(50 \mathrm{mg} / \mathrm{kg}$, intraperitoneally, Abbott Laboratories), according to the method of Mundlos et al. ${ }^{2}$. Controls were treated in the same way but received $50 \mu l$ of $0.9 \%$ saline. The rats in both groups were kept individually in metabolic cages for 4 weeks. Body weight and food intake were noted daily.

Four weeks after the treatment, the rats of both groups were deprived of food overnight. On the follow- ing morning, the rats were killed by cervical dislocation and bled. Plasma was obtained from trunk blood by centrifugation.

The whole pancreas, both parotid glands, and the small intestine were quickly removed. The whole pancreas, both parotid glands, and the small intestine from which the contents were removed were rinsed with ice-cold $0.9 \%$ saline and weighed and homogenized with ice-cold $0.02 \mathrm{M}$ phosphate buffer $(\mathrm{pH} 7.0)$ containing $0.05 \mathrm{M} \mathrm{NaCl}$ in a Potter-Elvehjem glass homogenizer with a Teflon pestle. The homogenate was centrifuged at $2,000 \mathrm{~g}$ for $20 \mathrm{~min}$ at $4^{\circ} \mathrm{C}$, and the supernatant was used for the assay of amylase activity.

In the second experiment, the effects of exocrine pancreatic insufficiency were examined in the fed state. Exocrine pancreatic insufficiency was induced using the same procedure as in the first experiment. To obtain constant food intake during the feeding experiment, periodic food restrictions ${ }^{3)}$ were imposed on both the oleic acid-treated rats and saline-treated control rats by limiting the free food access to $4 \mathrm{~h}$ per day, from 10 a. m. to 2 p. m., while water was given $a d$ libitum, 4 weeks after the oleic acid or saline treatment. Body weight and food intake were noted daily. On the 11th day after the start of periodic food restrictions, the rats in both groups were allowed to eat for $1 \mathrm{~h}$ from $10 \mathrm{a} . \mathrm{m}$. and the amount of food and water consumed was noted. The rats were killed by cervical dislocation and bled $2 \mathrm{~h}$ after the start of feeding. Plasma was obtained from trunk blood by centrifugation.

The whole pancreas, both parotid glands, stomach, and small intestine were quickly removed. The whole pancreas and both parotid glands were rinsed with icecold $0.9 \%$ saline, and weighed, and homogenized with ice-cold $0.02 \mathrm{M}$ phosphate buffer ( $\mathrm{pH} 7.0$ ) containing $0.05 \mathrm{M} \mathrm{NaCl}$ in a Potter-Elvehjem glass homogenizer with a Teflon pestle. The homogenate was centrifuged $2,000 \mathrm{~g}$ for $20 \mathrm{~min}$ at $4^{\circ} \mathrm{C}$, and the supernatant was used for the assay of amylase activity.

The stomachs were dissected, and the contents removed, weighed and diluted with four volumes of icecold $0.9 \%$ saline and homogenized. The $\mathrm{pH}$ was measured at $4^{\circ} \mathrm{C}$, and the contents were neutralized 
with $100 \mathrm{mM} \mathrm{Na}_{2} \mathrm{HPO}_{4}$ solution. The intestinal contents were collected into a vessel by manual compression of the intestine, and weighed. The lumen of the intestine was rinsed with $5 \mathrm{~m} l$ of ice-cold $0.9 \%$ saline, and the effluent was added to the collected intestinal content. The intestinal content was further diluted with two volumes of ice-cold $0.9 \%$ saline, homogenized and the $\mathrm{pH}$ measured at $4^{\circ} \mathrm{C}$. The small intestine from which the contents were removed was weighed, and homogenized with ice-cold $0.02 \mathrm{M}$ phosphate buffer ( $\mathrm{pH} 7.0$ ) containing $0.05 \mathrm{M} \mathrm{NaCl}$ in a PotterElvehjem glass homogenizer with a Teflon pestle. The homogenate was centrifuged at $2,000 \mathrm{~g}$ for $20 \mathrm{~min}$ at $4^{\circ}$ $\mathrm{C}$, and the supernatant was used for the assay of amylase activity.

The suspensions of gastric and intestinal contents were centrifuged at $2,000 \mathrm{~g}$ for $20 \mathrm{~min}$ at $4^{\circ} \mathrm{C}$. The supernatant was stored, and the precipitate suspended in $10 \mathrm{~m} l$ of ice-cold $0.9 \%$ saline, homogenized and centrifuged. This procedure was repeated three times. The combined supernatant was used for the assay of amylase activity and soluble sugar concentration. Ten $\mathrm{m} l$ of water and $12 \mathrm{~m} l$ of $60 \%$ perchloric acid were added to the final precipitate. The mixture was kept cool by immersion in ice. Stirring was continued for 20 $\mathrm{min}$, then $8 \mathrm{~m} l$ of water added, before the mixture was centrifuged. The aqueous starch solution was stored, and the extraction of starch by perchloric acid was repeated two more times. The combined extract was used for the assay of starch concentration.

\section{Assays}

The amylase activity of the plasma, tissues, gastric, and intestinal contents was determined by the blue starch method described by Ceska et $a l .{ }^{4}$. The plasma insulin concentration was determined by radioimmunoassay, with rat insulin used as a standard (Incstar Co.), the plasma glucose concentration by the glucose oxidase method (Glucose $\mathrm{C}$-Test, Wako Pure Chemical Industries), and the plasma bilirubin concentration was determined by the Evelyn-Malloy method (Bilirubin-Test, Wako Pure Chemical Industries). The soluble sugar and starch concentrations in the gastric and intestinal contents were determined by the glucose-anthrone sulfuric acid reaction ${ }^{5}$, and expres- sed as mg glucose.

\section{Estimation of residual starch and absorption of carbohydrate}

The following particulars were determined:1) residual starch in the gastric content (\%);2) gastric emptying of carbohydrate $(\mathrm{mg}) ; 3)$ residual starch in the intestinal content (\%) ;4) intestinal absorption of carbohydrate (mg), as follows :

1) residual starch in the gastric content (\%)

$=\frac{\text { residual starch in the gastric content }(\mathrm{mg})}{\text { total carbohydrate in the gastric content }(\mathrm{mg})}$

$\times 100$

where total carbohydrate $(\mathrm{mg})=$ starch $(\mathrm{mg})+$ soluble sugar (mg)

2) gastric emptying of carbohydrate (mg)

$=$ total carbohydrate intake $(\mathrm{mg})$

- total carbohydrate in the gastric content $(\mathrm{mg})$

where total carbohydrate intake $(\mathrm{mg})=$ total carbohydrate in diet $(\mathrm{mg} / \mathrm{g}) \times$ food intake $(\mathrm{g})$

3) residual starch in the intestinal content (\%) $=\frac{\text { residual starch in the intestinal content }(\mathrm{mg})}{\text { gastric emptying of carbohydrate }(\mathrm{mg})}$ $\times 100$

and

4) intestinal absorption of carbohydrate $(\mathrm{mg})=$ gastric emptying of carbohydrate $(\mathrm{mg})$ - total carbohydrate in the intestinal content $(\mathrm{mg}$ )

\section{Separation of amylase isozymes}

Amylase isozymes in plasma, tissues, and in gastric and intestinal contents were separated on a thin layer of $7.5 \%$ polyacrylamide gel by electrophoresis using a method modified from Otsuki et al. ${ }^{6}$. Here, 2-amino2-methyl-1, 3-propanediol) (Wako Pure Chemical Industries) was used as the buffer instead of tris (hydroxymethyl) amino methane as in the standard buffer system, to clearly separate the more basic components of the amylase isozymes. Eight microliters of each sample $(1 \mathrm{U} / \mathrm{m} l)$ was applied to the gel, and electrophoresis was carried out at $4^{\circ} \mathrm{C}$ for $16 \mathrm{~h}$ at $1 \mathrm{~mA} / \mathrm{cm}$. After the electrophoresis, the gel plate was incubated for $30 \mathrm{~min}$ at $37^{\circ} \mathrm{C}$ in a starch solution ( $1 \mathrm{~g}$ soluble starch dissolved in $100 \mathrm{~m} l$ of boiling $0.02 \mathrm{M}$ phosphate buffer, $\mathrm{pH} 7.0$, containing $0.05 \mathrm{M}$ 

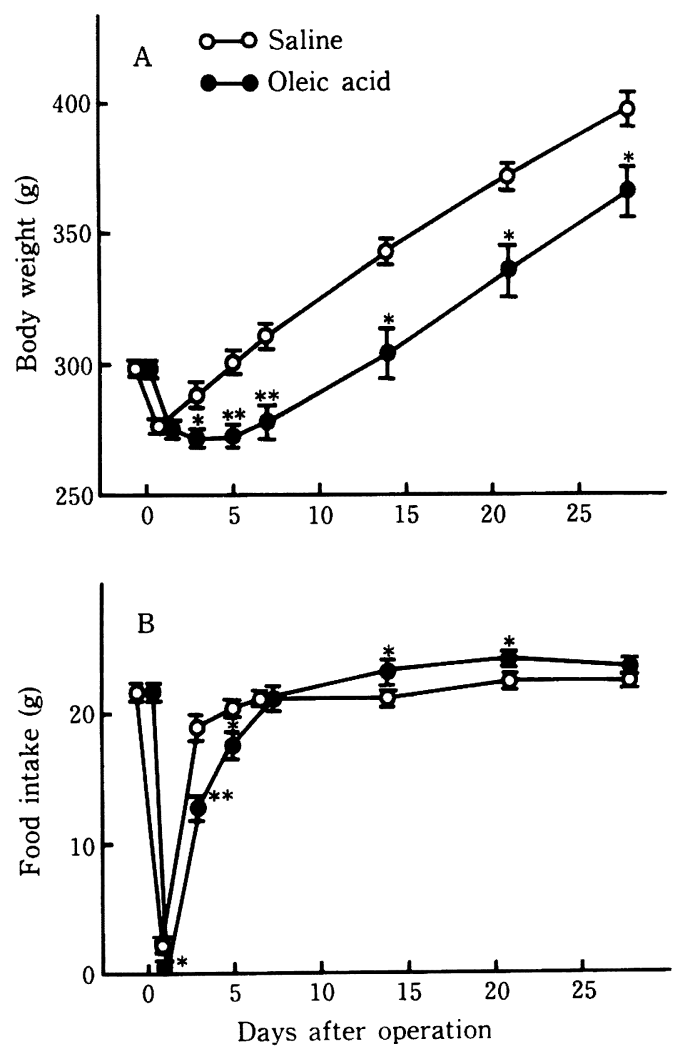

Fig. 1 Body weight (A) and food intake (B) of salinetreated controls $(n=11)$ and oleic acid-treated rats $(n=14)$ after operation in Experiment 1. Values are means $\pm \mathrm{SE}$. ${ }^{*} \mathrm{P}<0.05$ and ${ }^{* *} \mathrm{P}<0.001$, both vs. saline-treated controls.

$\mathrm{NaCl}$ ), followed by incubation of the plate alone at $37^{\circ}$ $\mathrm{C}$ for $5 \mathrm{~h}$. The gel plate was soaked in dilute acetic acid $(50 \mathrm{ml} / l)$ for $5 \mathrm{~min}$ before staining with an iodine/ potassium iodide solution ( $30 \mathrm{~g}$ of $\mathrm{KI}$ and $13 \mathrm{~g}$ of $\mathrm{I}_{2} / l$ ). The area where amylase activity was present was identified as a light yellow band against a dark blue backkground. The stained gels were photographed, and the photographs were scanned with a densitometer (Densitron, PAN-802, Joko) using a $0.2 \times 10-\mathrm{mm}$ slit beam $(500 \mathrm{~nm})$. The proportions of isozymes were calculated from the ratio of the area using a built-in integrator.

\section{Statistics}

The significance of the results was determined by Student's $t$-test or Chochran's $t$ test.
Table 1 Body weight and food intake of salinetreated controls and oleic acid-treated rats on the 10th day after the start of periodic food restrictions in Experiment 2

\begin{tabular}{lcc}
\hline & $\begin{array}{c}\text { Body weight } \\
(\mathrm{g})\end{array}$ & $\begin{array}{c}\text { Food intake } \\
(\mathrm{g})\end{array}$ \\
\hline Salin (11) & $325 \pm 10$ & $14.7 \pm 0.4$ \\
Oleic acid (13) & $344 \pm 4$ & $12.9 \pm 0.6$ \\
P vs. Saline & $\mathrm{NS}$ & $<0.02$ \\
\hline
\end{tabular}

Values are means \pm SE. Numbers of animals in parentheses.

NS : not significant.

\section{Results}

\section{Body weight and food intake}

In the first experiment, the body weight of the oleic acid-treated rats decreased immediately after the operation (Fig. 1A) due to the marked decrease in food intake (Fig. 1B). Recovery of food intake was gradual from the second to the seventh day after the operation. From the seventh to the 28th day after the operation, the increase in body weight was similar for the oleic acid-treated rats and the saline-treated control rats. The food intake of oleic acid-treated rats 28 days after the operation did not differ from that of the saline-treated control rats.

In the second experiment, the changes in both body weight and food intake of the two groups for 28 days after the operation were the same as in the first experiment. From the seventh to the 10th day after the start of periodic food restrictions, the food intake of both two groups became constant. The body weight of the oleic acid-treated rats on the 10th day after the start of periodic food restrictions did not statistically differ from that of the saline-treated control rats, while the food intake of oleic acid-treated rats was significantly higher than that of the saline-treated control rats (Table 1 ).

\section{Weight, and amylase activity in the pancreas, parotid glands, and small intestine}

In the first experiment, the weight of the pancreas 
Table 2 Weight of pancreas, parotid glands, and small intestine in saline treated controls and oleic acid-treated rats in Experiment 1

\begin{tabular}{lccc}
\hline & \multicolumn{3}{c}{ Weight $(\mathrm{g})$} \\
\cline { 2 - 4 } & Pancreas & Parotid glands & Small intestine \\
\hline Saline (11) & $1.271 \pm 0.049$ & $0.459 \pm 0.018$ & $5.78 \pm 0.16$ \\
Oleic acid (14) & $0.279 \pm 0.023$ & $0.496 \pm 0.023$ & $6.98 \pm 0.24$ \\
P vs. Saline & $<0.001$ & NS & $<0.001$ \\
\hline
\end{tabular}

Values are means \pm SE. Numbers of animals in parentheses. NS : not significant.

Experiment 1 was performed after overnight fasting.

Table 3 Amylase activity in pancreas, parotid glands, and small intestine in saline-treated controls and oleic acid-treated rats

\begin{tabular}{cccc}
\hline & \multicolumn{3}{c}{ Amylase activity (U/g) } \\
\cline { 2 - 4 } & Pancreas & Parotid glands & Small intestine \\
\hline Experiment 1 & & & \\
Saline (11) & $18,700 \pm 2,300$ & $86,100 \pm 4,100$ & $69 \pm 4$ \\
Oleic acid (14) & $759 \pm 298$ & $81,500 \pm 3,700$ & $14 \pm 3$ \\
P vs. Saline & $<0.001$ & $\mathrm{NS}$ & $<0.001$ \\
Experiment 2 & & & \\
Saline (11) & $20,200 \pm 2100$ & $48,700 \pm 3,500$ & $254 \pm 25$ \\
Oleic acid (13) & $868 \pm 160$ & $46,500 \pm 2,600$ & $7 \pm 1$ \\
P vs Saline & $<0.001$ & $\mathrm{NS}$ & $<0.001$ \\
\hline
\end{tabular}

Values are means \pm SE. Number of animals in parentheses. NS : not significant. Experiment 1 was performed after overnight fasting. Experiment 2 was performed one hour after $1 \mathrm{~h}$ of feeding.

of the oleic acid-treated rats in the fasting state 28 days after the operation was markedly lower than in the saline-treated control rats (Table 2). The weight of the parotid glands of the oleic acid-treated rats did not differ from that of the saline-treated control rats. The weight of the small intestine of the oleic acidtreated rats was significantly higher than in the salinetreated control rats.

Table 3 shows the amylase activity of the pancreas, parotid glands, and the small intestine in both the fasting and fed states. The pancreatic amylase activity of the oleic acid-treated rats was markedly lower than in the saline-treated control rats in both the fasting and fed states. There were no differences between the amylase activity in the parotid glands of the oleic acid-treated rats and the saline-treated control rats in either the fasting or fed states. The amylase activity in the small intestine of the oleic acid -treated rats was markedly lower than in the salinetreated control rats in both the fasting and fed states.

\section{Plasma insulin, glucose, bilirubin concentra- tions, and amylase activity}

The plasma insulin, glucose, bilirubin concentrations, and amylase activity were similar for the oleic acid-treated rats and saline-treated control rats in both the fasting and fed states (Table 4). The electrophoresis of amylase isozymes in the plasma samples showed that the amylase isozyme in the plasma of the two groups was mostly all of the parotid-type in the 
Table 4 Plasma insulin, glucose, bilirubin concentrations, and amylase activity in saline-treated controls and oleic acid-treated rats

\begin{tabular}{ccccc}
\hline & $\begin{array}{c}\text { Insulin } \\
(\mathrm{ng} / \mathrm{m} l)\end{array}$ & $\begin{array}{c}\text { Glucose } \\
(\mathrm{mg} / \mathrm{d} l)\end{array}$ & $\begin{array}{c}\text { Bilirubin } \\
(\mathrm{mg} / \mathrm{d} l)\end{array}$ & $\begin{array}{c}\text { Amylase } \\
\text { activity } \\
(\mathrm{U} / \mathrm{m} l)\end{array}$ \\
\hline Experiment 1 & & & & \\
Saline (11) & $1.9 \pm 0.2$ & $122 \pm 4$ & $<0.1$ & $4.92 \pm 0.26$ \\
Oleic acid (14) & $1.8 \pm 0.2$ & $112 \pm 4$ & $<0.1$ & $5.18 \pm 0.27$ \\
P vs. Saline & $\mathrm{NS}$ & $\mathrm{NS}$ & $\mathrm{NS}$ & $\mathrm{NS}$ \\
Experiment 2 & & & & $12.60 \pm 1.27$ \\
Saline (11) & $8.6 \pm 1.4$ & $130 \pm 3$ & $<0.1$ & $11.73 \pm 0.97$ \\
Oleic acid (13) & $10.5 \pm 1.6$ & $137 \pm 4$ & $<0.1$ & $\mathrm{NS}$ \\
P vs. Saline & $\mathrm{NS}$ & $\mathrm{NS}$ & $\mathrm{NS}$ & \\
\hline
\end{tabular}

Values are means \pm SE. Number of animals in parentheses. NS : not significant. Experiment 1 was performed after overnight fasting. Experiment 2 was performed one hour after $1 \mathrm{~h}$ of feeding.

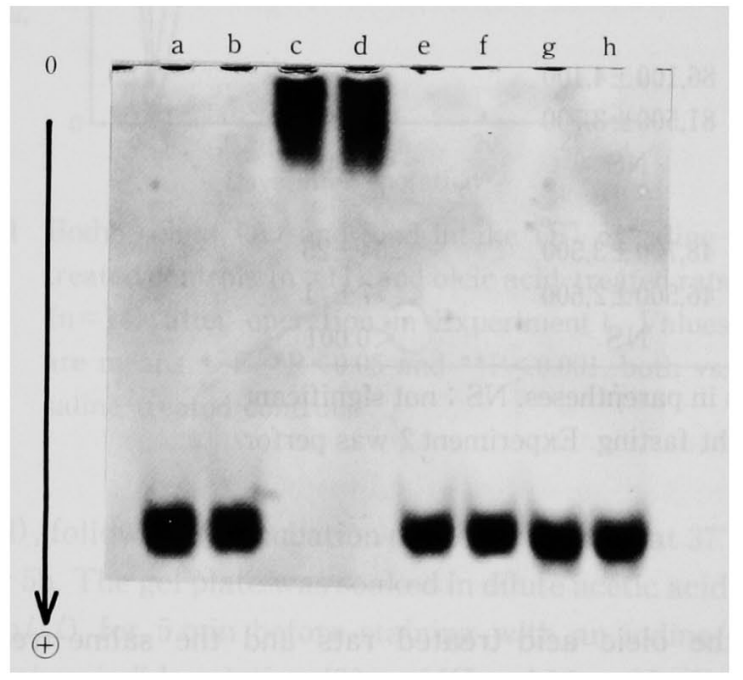

Fig. 2 Amylase isozyme determined in parotid glands (a, b), pancreas (c, d), plasma $(e, f)$ of saline-treated controls, and plasma $(\mathrm{g}, \mathrm{h})$ of oleic acid-treated rats in the fasting state in Experiment 1. 0 : origin, $\oplus$ : anode.

fasting state (Fig. 2).

4. Carbohydrate intake; weight, pH, amylase activity, soluble sugar, and residual starch in gastric contents; and gastric emptying of carbohydrate (Table 5)

Carbohydrate intake during the $1 \mathrm{~h}$ feeding; weight of gastric content : amylase activity, soluble sugar, and residual starch in the gastric contents ; and gastric emptying of carbohydrate one hour after the $1 \mathrm{~h}$ feeding were similar for the oleic acid-treated rats and saline-treated control rats. The $\mathrm{pH}$ of the gastric content one hour after the $1 \mathrm{~h}$ feeding was significantly lower in the oleic acid-treated rats than in the salinetreated control rats.

5. Weight, pH, amylase activity, soluble sugar, and residual starch in intestinal contents : and intestinal absorption of carbohydrate

Table 6 shows the weight of the intestinal content ; $\mathrm{pH}$, amylase activity, soluble sugar, and residual starch in intestinal contents; and intestinal absorption of carbohydrate one hour after the $1 \mathrm{~h}$ feeding. The weight of the intestinal contents was significantly higher in the oleic acid-treated rats than in the salinetreated control rats. The $\mathrm{pH}$ and soluble sugar of the intestinal contents did not differ between the two groups. The amylase activity of the intestinal contents was markedly lower in the oleic acid-treated rats than in the saline-treated control rats, while the percentage of residual starch in the intestinal contents was significantly higher in the oleic acid-treated rats than in the saline-treated control rats. The intestinal absorption of carbohydrate did not differ between the two groups. The percentage of residual starch was 
Table 5 Carbohydrate intake : weight, $\mathrm{pH}$, amylase activity, soluble sugar, residual starch in gastric contents ; and gastric emptying of carbohydrate in saline-treated controls and oleic acid-treated rats in Experiment 2

\begin{tabular}{lcccccccc}
\hline & $\begin{array}{c}\text { Carbo- } \\
\text { hydrate } \\
\text { intake } \\
(\mathrm{mg})\end{array}$ & $\begin{array}{c}\text { Weight } \\
(\mathrm{g})\end{array}$ & $\mathrm{pH}$ & $\begin{array}{c}\text { Amylase } \\
\text { activity } \\
(\mathrm{U} / \mathrm{g})\end{array}$ & $\begin{array}{c}\text { Soluble } \\
\text { sugar } \\
(\mathrm{mg} / \mathrm{g})\end{array}$ & $\begin{array}{c}\text { Residual } \\
\text { starch } \\
(\mathrm{mg} / \mathrm{g})\end{array}$ & $\begin{array}{c}\text { Residual } \\
\text { starch* } \\
(\%)\end{array}$ & $\begin{array}{c}\text { Gastric } \\
\text { emptying } \\
\text { of carbo- } \\
\text { hydrate } \\
(\mathrm{mg})\end{array}$ \\
\hline & 3,899 & 11.20 & 5.89 & 148 & 94 & 128 & 57.4 & 1,442 \\
Saline & \pm & \pm & \pm & \pm & \pm & \pm & \pm & \pm \\
$(11)$ & 208 & 0.81 & 0.03 & 26 & 3 & 6 & 1.8 & 107 \\
& 4,047 & 11.31 & 5.79 & 223 & 97 & 124 & 56.3 & 1,540 \\
Oleic acid & \pm & \pm & \pm & \pm & \pm & \pm & \pm & \pm \\
$(13)$ & 251 & 1.03 & 0.03 & 36 & 5 & 4 & 1.9 & 55 \\
P vs. Saline & $\mathrm{NS}$ & $\mathrm{NS}$ & $<0.05$ & NS & NS & NS & NS & NS \\
\hline
\end{tabular}

Values are means \pm SE. Number of animals in parentheses. NS : not significant. Experiment 2 was performed one hour after $1 \mathrm{~h}$ of feeding. ${ }^{*}$ : The starch in diet (\%) is $86.8^{1}$.

Table 6 Weight, $\mathrm{pH}$, amylase activity, soluble sugar, residual starch in intestinal contents : and intestinal absorption of carbohydrate in saline-treated controls and oleic acid-treated rats in Experiment 2

\begin{tabular}{|c|c|c|c|c|c|c|c|}
\hline & \multicolumn{6}{|c|}{ Intestinal content } & \multirow{2}{*}{$\begin{array}{c}\text { Intestinal } \\
\text { absorption of } \\
\text { carbohydrate } \\
\text { (mg) }\end{array}$} \\
\hline & $\begin{array}{l}\text { Weight } \\
\text { (g) }\end{array}$ & $\mathrm{pH}$ & $\begin{array}{c}\text { Amylase } \\
\text { activity } \\
\text { (U/g) }\end{array}$ & $\begin{array}{c}\text { Soluble } \\
\text { sugar } \\
(\mathrm{mg} / \mathrm{g})\end{array}$ & $\begin{array}{c}\text { Residual } \\
\text { starch } \\
(\mathrm{mg} / \mathrm{g}) \\
\end{array}$ & $\begin{array}{l}\text { Residual } \\
\text { starch } \\
(\%)\end{array}$ & \\
\hline $\begin{array}{l}\text { Saline } \\
\text { (11) }\end{array}$ & $\begin{array}{c}3.64 \\
\pm \\
0.24\end{array}$ & $\begin{array}{c}7.53 \\
\pm \\
0.03\end{array}$ & $\begin{array}{c}1,536 \\
\pm \\
97\end{array}$ & $\begin{array}{c}26 \\
\pm \\
1\end{array}$ & $\begin{array}{l}18 \\
\pm \\
1\end{array}$ & $\begin{array}{l}4.6 \\
\pm \\
0.2\end{array}$ & $\begin{array}{c}1,282 \\
\pm \\
98\end{array}$ \\
\hline $\begin{array}{l}\text { Oleic acid } \\
\text { (13) }\end{array}$ & $\begin{array}{c}5.33 \\
\pm \\
0.24\end{array}$ & $\begin{array}{c}7.56 \\
\pm \\
0.03\end{array}$ & $\begin{array}{l}89 \\
\pm \\
19\end{array}$ & $\begin{array}{c}25 \\
\pm \\
1\end{array}$ & $\begin{array}{l}34 \\
\pm \\
3\end{array}$ & $\begin{array}{c}12.0 \\
\pm \\
1.3\end{array}$ & $\begin{array}{c}1,229 \\
\pm \\
60\end{array}$ \\
\hline $\mathrm{P}$ vs. Saline & $<0.001$ & NS & $<0.001$ & NS & $<0.001$ & $<0.001$ & NS \\
\hline
\end{tabular}

Values are means \pm SE. Number of animals in parentheses. NS : not significant.

Experiment 2 was performed one hour after $1 \mathrm{~h}$ of feeding.

inversely correlated with the amylase activity in the intestinal contents of the oleic acid-treated rats, while this was not the case with the saline-treated control rats (Fig. 3).

\section{Amylase isozymes (Fig. 4 and Table 7)}

Most of the amylase isozyme in the small intestine and in the intestinal contents of the saline-treated control rats one hour after the $1 \mathrm{~h}$ feeding was of the pancreatic-type, while most of the amylase isozyme in the small intestine and in the intestinal contents of oleic acid-treated rats was of the parotid-type.

\section{Discussion}

The atrophied pancreas of the oleic acid-treated rats showed reduced amylase activity in both the fasting and fed states. This indicates that oleic acid treatment induces exocrine pancreatic insufficiency with reduced secretion of amylase in rats. On the other hand, the plasma insulin and glucose concentrations of the oleic acid-treated rats did not differ from those of the saline-treated control rats in either the fasting or fed states. This is consistent with a previous 


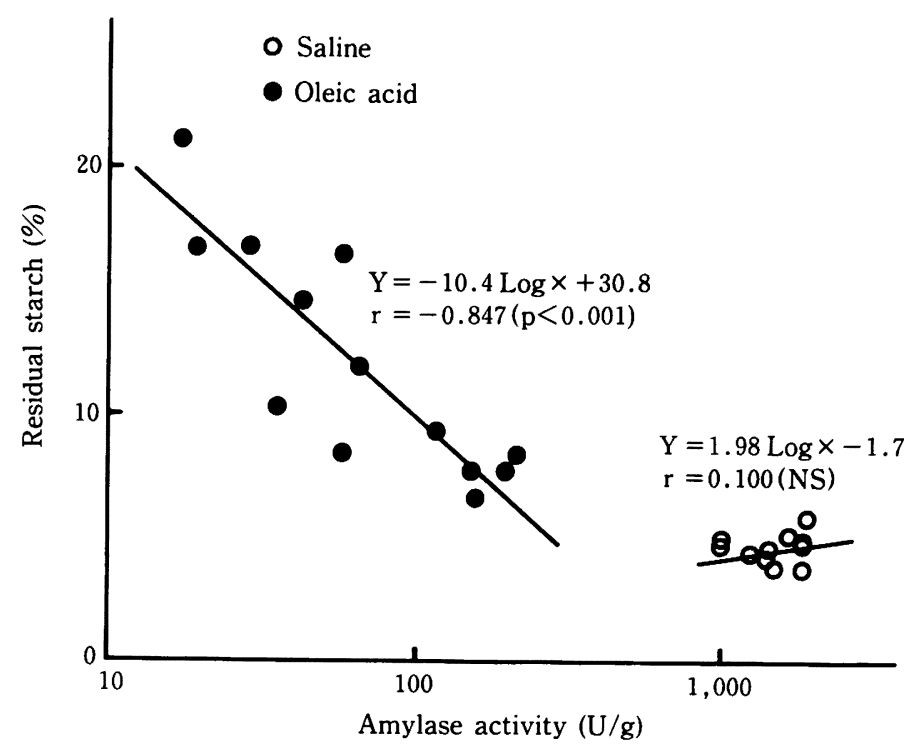

Fig. 3 Correlation between residual starch (\%) and amylase activity in the intestinal content $(\mathrm{U} / \mathrm{g})$ of saline-treated controls and oleic acid-treated rats one hour after $1 \mathrm{~h}$ of feeding in Experiment 2. NS : not significant.

study ${ }^{8)}$ indicating that the endocrine pancreatic function in oleic acid-treated rats is within the normal range. The plasma bilirubin concentration and amylase activity did not differ between the oleic acidtreated rats and saline-treated control rats in either the fasting or fed states, and the amylase isozyme in the plasma of the oleic acid-treated rats was mostly of the parotid-type in the fasting state as with the saline-treated control rats. These results indicate that the oleic acid-treated rats do not suffer from cholestasis or acute pancreatitis 28 days after the operation.

From the seventh to the 28th day after the operation, increase in body weight was similar between both groups. Seven to 28 days after the operation, the rats appeared to have adapted to exocrine pancreatic insufficiency by the reduced secretion of amylase.

The amylase activity in the parotid glands did not differ between the exocrine pancreatic insufficient rats and the control rats in either the fasting or fed states. The amylase activity in the gastric contents was also similar for both groups. It seems that exocrine pancreatic insufficiency alone does not affect either the parotid amylase activity or the amylase secretion from the parotid glands during feeding.
The percentage of starch decreased from 86.8 in the pellet diet to 57.4 in the gastric content of control rats and to 56.3 in the gastric content of exocrine pancreatic insufficient rats respectively, indicating that about one third of the ingested starch was digested in the stomachs of both groups. Parotid-type amylase appears to work in the oral cavity and stomach of the exocrine pancreatic insufficient rats, similar to the situation in both the control rats and the rats with pancreatitis ${ }^{1}$.

In the exocrine pancreatic insufficient rats, a large part of the amylase activity in the small intestine and in the intestinal contents was shown to derive from the parotid glands. This result is consistent with that concerning rats with pancreatitis ${ }^{1}$. Further, parotidtype amylase activity in the intestinal contents seems to be higher in the exocrine pancreatic insufficient rats than in the control rats. Both the reduced secretion of proteolytic enzyme from pancreas and the presence of bile in the small intestine may be related to the prolonged presence of parotid-type amylase in the intestinal contents of exocrine pancreatic insufficient rats.

Although the amylase activity in the small intestine 


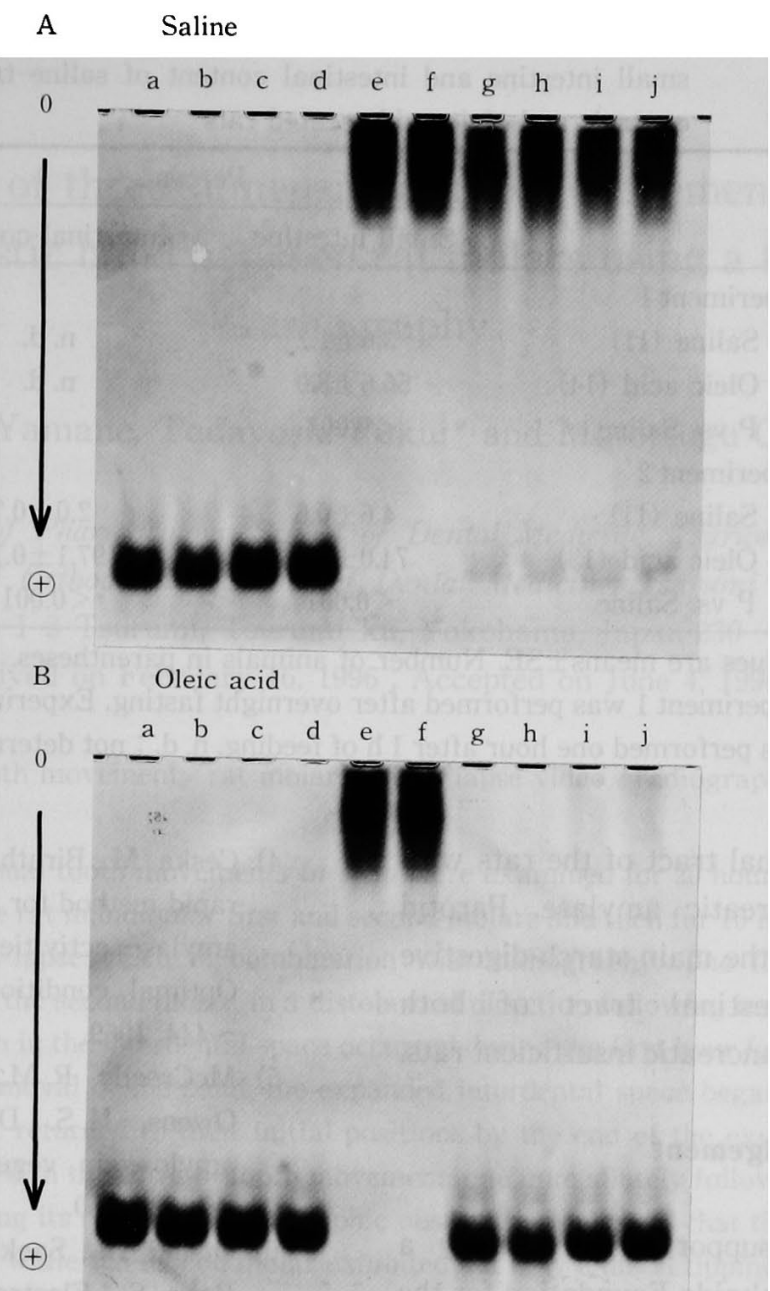

Fig. 4 Amylase isozyme determined in parotid glands (a, b), gastric content (c, d), pancreas (e,f), intestinal content $(g, h)$, and small intestine $(i, j)$ of salinetreated controls $(\mathrm{A})$, and oleic acid-treated rats

(B) one hour after $1 \mathrm{~h}$ of feeding in Experiment 2.

$\mathrm{O}$ : origin, $\oplus$ : anode.

and in the intestinal content one hour after the $1 \mathrm{~h}$ feeding was lower in the exocrine pancreatic insufficient rats than in the control rats, the percentage of residual starch decreased from 56.3 in the gastric contents to 12.0 in the intestinal contents. Moreover, the percentage of residual starch was inversely correlated with the amylase activity in the intestinal contents of the exocrine pancreatic insufficient rats, while this correlation was not observed in the control rats. The intestinal absorption of carbohydrate and plasma insulin concentration after the $1 \mathrm{~h}$ feeding did not differ between the exocrine pancreatic insufficient rats and the controls. In the hypertrophied small intestine of the exocrine pancreatic insufficient rats, a small quantity of parotid-type amylase seemed to effectively digest a large part of the starch by the better mixing of intestinal contents.

The results confirmed that amylase secreted from the parotid glands and moving from the stomach to the small intestine, plays a physiological role in starch digestion in the gastrointestinal tract of rats with reduced secretion of pancreatic amylase. The increased amylase activity in parotid glands seems not to be necessary for the physiological role of parotid 
Table 7 Parotid amylase as a percentage of total amylase for small intestine and intestinal content of saline-treated controls and oleic acid-treated rats

\begin{tabular}{ccc}
\hline & \multicolumn{2}{c}{ Percent } \\
\cline { 2 - 3 } & Small intestine & Intestinal content \\
\hline Experiment 1 & $3.6 \pm 1.2$ & n. d. \\
Saline (11) & $56.6 \pm 8.0$ & n. d. \\
Oleic acid (14) & $<0.001$ & \\
P vs. Saline & & \\
Experiment 2 & $4.6 \pm 0.6$ & $2.0 \pm 0.7$ \\
Saline (11) & $74.0 \pm 3.0$ & $97.1 \pm 0.7$ \\
Oleic acid (13) & $<0.001$ & $<0.001$ \\
P vs. Saline & & \\
\hline
\end{tabular}

Values are means \pm SE. Number of animals in parentheses.

Experiment 1 was performed after overnight fasting. Experiment 2 was performed one hour after $1 \mathrm{~h}$ of feeding. n. d. : not determined.

amylase in the gastrointestinal tract of the rats with reduced secretion of pancreatic amylase. Parotid amylase is considered to be the main starch digestive enzyme in the gastrointestinal tract of both endocrine ${ }^{9,10)}$ and exocrine pancreatic insufficient rats.

\section{Acknowledgement}

This investigation was supported in part by a research grant from the Hokkaido Foundation for the Promotion of Scientific and Industrial Technology. We are grateful to Professor T. Christensen, Hokusei Junior College, for proofreading this manuscript.

\section{References}

1) Kurahashi, M. and Inomata, K.: Starch digestion by parotid amylase in the gastrointestinal tract of rats with pancreatitis. Jpn. J. Oral Biol. 38: 326 $\sim 334,1996$.

2) Mundlos, S., Adler, G., Schaar, M., Koop, I. and Arnold, R. : Exocrine pancreatic function in oleic acid-induced pancreatic insufficiency in rats. Pancreas $1:$ 29 36, 1986.

3) Hoshi, M., Kurahashi, M., Inomata, K., Obara, N. and Takeda, M. : Autonomic regulation of amylase secretion from von Ebner's glands in rats during feeding. Dentistry in Japan 30:40 43, 1993.
4) Ceska, M., Birath, K. and Brown, B. : A new and rapid method for the clinical determination of $\alpha$ amylase activities in human serum and urine. Optimal conditions. Clin. Chim. Acta 26:437 $\sim 444,1969$.

5) McCready, R. M., Guggolz, J., Silviera, V. and Owens, H.S. : Determinations of starch and amylose in vegetables. Anal. Chem. 22:1156 $\sim 1158,1950$.

6) Otsuki, M., Saeki, S., Yuu, H., Maeda, M. and Baba, S. : Electrophoretic pattern of amylase isozyme in serum and urine of normal persons. Clin. Chem. 22: 439 444, 1976.

7) Tamura, H. and Ui, N. : A new buffer system for disc electrophoresis suitable for slightly basic proteins. J. Biochem. 71: 543 545, 1972.

8) Göke, B., Elsebach, K., Hausmann, W., Schaar, M., Arnold, R. and Adler, G. : Endocrine pancreatic morphology and function in exocrine insufficiency in rats. Am. J. Physiol. 253 (Gastrointest. Liver Physiol. 16) : G139 G145, 1987.

9) Kurahashi, M. and Inomata, K. : Amylase secretion by parotid glands and pancreas of diabetic rats during feeding. Am. J. Physiol. 254 (Gastrointest. Liver Physiol. 17) : G878 G882, 1988.

10) Kurahashi, M. and Inomata, K. : Role of parotid amylase in starch digestion in the gastro-intestinal tracts of diabetic rats. J. Dent. Res. 68: 1366 〜1369, 1989. 